\title{
Investigation and Development of the Technology of Processing Gold-Antimony Flotation Concentrates
}

\author{
Rostislav E. Rusalev*a, Sergei V. Grokhovskii ${ }^{\text {a }}$, \\ Denis A. Rogozhnikov ${ }^{\mathrm{b}}$ and Stanislav S. Naboichenko ${ }^{\mathrm{b}}$ \\ ${ }^{a} L L C$ EZ OCM-ENGINEERING \\ 131 Uspensky, Verkhnyaya Pyshma, 624097, Russia \\ ${ }^{b}$ Ural Federal University \\ named after the First President of Russia B.N. Yeltsin \\ 19 Lenin, Ekaterinburg, 620083, Russia
}

Received 15.01.2018, received in revised form 04.02.2018, accepted 20.02.2018

Hydrometall urgicalinvestigations of gold antimony flotation concentrate have been carriedout. $X R D$ and chemicalanalysesoftheconcentratehave beenstudied. Mainly, the material consists of compoundsofantimony, silicon, calcium, sulfur and iron. The main phases are quartz, stibnite, calcium carbonate and ankerite, pyrite and arsenopyrite have been found as well. The feature of an timonite'sdissolvinginalkaline solutions has been reviewed. The dependencesofeffectsofthetemperatu re, time, L/Sratioand $\mathrm{NaOH}$ concentration on the extraction antimony and sulfur from the flotation concentrate have been determined. During sulphide-alkaline leaching of the starting material several physicochemical characteristics of gold dissolution has been identified.

Agitated cyanide gold leaching test of the disantimoniedcake was conducted. Goldrecoverywas $32,2 \%$. The obtained low indexes of gold recovery are based on cyanidation. A nitric acid leaching of disantimonied cake was proposed.

Keywords: flotationconcentrate, antimony, gold, alkaline leaching, cyanidation.

Citation: Rusalev R.E., Grokhovskii S.V., Rogozhnikov D.A., Naboichenko S.S. Investigation and development of the technology of processing gold-antimony flotation concentrates, J. Sib. Fed. Univ. Chem., 2018, 11(1), 110-121. DOI: 10.17516/1998-28360062.

(C) Siberian Federal University. All rights reserved

* Corresponding author E-mail address: rusalevrostislav@gmail.com 


\title{
Исследование и разработка технологии переработки золотосурьмяного флотационного концентрата
}

\author{
Р.Э. Русалев ${ }^{a}$, С.В. Гроховский \\ Д.А. Рогожников ${ }^{\sigma}$, С.С. Набойченко \\ ${ }^{a} О О О$ «ЕЗ ОЦМ-ИНЖИНИРИНГ» \\ Россия, 624097, Верхняя Пьима, пр. Успенский, 131 \\ ${ }^{6}$ Уральский федеральный университет \\ им. первого Президента России Б.Н. Ельиина \\ Россия, 620083, Екатеринбург, пр. Ленина, 51
}

Проведены исследования по гидрометаллургической переработке золотосурьмяного флотационного концентрата. Изучены элементный и фазовый составы исходного материала. Концентрат представлен в основном соединениями сурьмы, кремния, кальция, серы и железа. Основными фазами являются: квари, стибнит, карбонат кальиия и анкерит, также обнаружены пирит и арсенопирит. Рассмотрены особенности растворения стибнита в сульфидно-щелочных растворах. Определены зависимости влияния температуры, времени, соотночения Ж:T и концентрации NaOH на извлечение сурьмы и серы из флотационного концентрата. Установлена вероятность перехода золота при сульфидно-щелочном выщелачивании исходного материала. Определены некоторые физикохимические характеристики растворения золота при сульфидно-щелочном выщелачивании. Проведены опыты по агитационному циианидному выщелачиванию золота из обессурьмянистого кека. Извлечение золота составило 32,2 \%. На основании полученных низких показателей извлечениязолота при циианировании предложен способ предварительного вскрытия обессурьмянистого кека - азотнокислотное выщелачивание.

Ключевые слова: флотокониентрат, сурьма, золото, сульфидно-щелочное выщелачивание, ичианирование.

\section{Введение}

Тенденция необходимости переработки сурьмянистых золотосодержащих руд становится все более актуальной. По некоторым данным [1], доля переработки таких руд очень мала. В России золотодобывающие компании складируют такие материалы на специальных полигонах либо продают в Китай на сурьмянистые заводы. Извлечение золота традиционными методами [2] из такого сырья малоэффективно. А извлечение одной только сурьмы из подобных материалов является нерациональным.

В настоящее время в мировой практике существует большое многообразие технологий по переработке упорных сульфидных золотосодержащих концентратов [3]. Сложность и капиталоемкость традиционных технологий становятся причинами разработок альтернативных технологий, направленных на повышение экологической безопасности и снижение капитальных и эксплуатационных затрат. Недостатки существующих методов подготовки упорных сульфидных золотосодержащих руд и концентратов подробно рассмотрены и описаны $[4,5]$. Однако 
высокое содержание сурьмы меняет технологию подготовки сульфидного золотосодержащего концентрата к цианированию.

Основным минералом сурьмы является стибнит, присутствующий почти во всех генетических типах сурьмяных месторождений. Сурьму чаще всего получают пирометаллургическими методами, однако при выборе комплексной схемы переработки золото-сурьмянистых концентратов не менее важна экономическая составляющая. При текущих ценах на сурьму рентабельность переработки низкосортных концентратов пирометаллургическими способами становится нерентабельной.

Золотосурьмянистые руды отличаются высоким содержанием золота (от 1,5 до 8 г/т) и сурьмы (от 0,6 до 10 \%), однако считается трудным объектом для цианирования. Минералы сурьмы, взаимодействуя со щелочными цианистыми растворами, резко снижают извлечение золота и приводят к повышенному расходу реагентов [6].

Золотосульфидный концентрат перерабатывают различными способами в зависимости от содержания сурьмы. Так, например, компания GeoProMining Ltd, самый крупный производитель золотосурьмянистых концентратов в России, использует комбинированную схему извлечения золота и сурьмы. Сперва золото извлекают гравитационным способом, выделяя крупные частицы. Затем хвосты гравитации подвергаются флотации с получением золотосурьмяного концентрата [7], который является конечным продуктом.

При низком содержании соединений сурьмы и высоком содержании пирита и арсенопирита концентрат подвергают окислительному обжигу с последующим цианированием. При содержании сурьмы в концентратах от 10 до 20 \% его отправляют на гидрометаллургическую переработку.

Цель настоящей работы - провести аналитические исследования сырья с определением элементного и фазового составов; подобрать параметры сульфидно-щелочного выщелачивания стибнита; выявить особенности азотнокислотоного вскрытия труднорастворимых соединений золотосурьмяного флотационного концентрата АО «Полюс».

\section{Теоретическая часть}

Из-за проявления амфотерных свойств сурьма растворяется как в кислотных, так и в щелочных растворах. Однако в промышленности в основном применяют водную смесь сульфида натрия и едкого натра для растворения стибнита. Щелочные растворы сульфида натрия действуют как универсальный и селективный растворитель для большинства сурьмянистых минералов. Однако исключением может быть мышьяк, олово и ртуть [8].

Растворение стибнита можно описать следующей реакцией:

$$
\begin{aligned}
& \mathrm{Sb}_{2} \mathrm{~S}_{3(\mathrm{тв})}+3 \mathrm{Na}_{2} \mathrm{~S}_{(\text {ж) }}=2 \mathrm{Na}_{2} \mathrm{SbS}_{3(\text { ж) }} \\
& \Delta \mathrm{G}_{298}^{0}=-71,41 \text { кДж/моль. }
\end{aligned}
$$

Изменение свободной энергии Гиббса имеет отрицательное значение, соответственно, реакция является термодинамически вероятной. Добавление гидроксида натрия играет очень важную роль в растворении стибнита [9]. В первую очередь, гидроксид натрия препятствует гидролизу $\mathrm{Na}_{2} \mathrm{~S}$, реакция может протекать в две стадии:

$$
-112-
$$




$$
\begin{aligned}
& \mathrm{Na}_{2} \mathrm{~S}+\mathrm{H}_{2} \mathrm{O}=\mathrm{NaHS}+\mathrm{NaOH}, \\
& \Delta \mathrm{G}_{298}^{0}=-66,99 \text { кДж/моль, } \\
& \mathrm{NaHS}+\mathrm{H}_{2} \mathrm{O}=\mathrm{H}_{2} \mathrm{~S}+2 \mathrm{NaOH}, \\
& \Delta \mathrm{G}_{298}^{0}=-79,65 \text { кДж/моль. }
\end{aligned}
$$

Суммарная реакция химических взаимодействий 2 и 3

$$
\mathrm{Na}_{2} \mathrm{~S}+2 \mathrm{H}_{2} \mathrm{O}=\mathrm{H}_{2} \mathrm{~S}+2 \mathrm{NaOH} \text {. }
$$

В условиях, когда в смеси растворов $\mathrm{Na}_{2} \mathrm{~S}$ и $\mathrm{NaOH}$ становится недостаточно сульфида натрия - основного растворителя, $\mathrm{NaOH}$ не только выступает как подавитель гидролиза $\mathrm{Na}_{2} \mathrm{~S}, \mathrm{Ho}$ и действует как дополнительный растворитель сурьмы в соответствии с реакцией 5 [11]:

$$
\mathrm{Sb}_{2} \mathrm{~S}_{3}+6 \mathrm{NaOH}=\mathrm{Na}_{3} \mathrm{SbS}_{3}+\mathrm{Na}_{3} \mathrm{SbO}_{3}+3 \mathrm{H}_{2} \mathrm{O} .
$$

Сульфид натрия может также реагировать с кислородом и диоксидом углерода, присутствующим в атмосфере воздуха, в соответствии с реакциями [12]

$$
\begin{aligned}
& \mathrm{Na}_{2} \mathrm{~S}+3 / 2 \mathrm{O}_{2}=\mathrm{Na}_{2} \mathrm{SO}_{3}, \\
& 2 \mathrm{Na}_{2} \mathrm{~S}+\mathrm{H}_{2} \mathrm{O}+\mathrm{CO}_{2}=2 \mathrm{NaHS}+\mathrm{Na}_{2} \mathrm{CO}_{3} .
\end{aligned}
$$

Реакции 1 и 5 описывают процесс растворения стибнита в сульфидно-щелочных растворах и представляют собой сложную систему различных элементов ( $\mathrm{Sb}, \mathrm{S}, \mathrm{Na})$, которые образуют комплексные ионы [13]. Побочные реакции 6 и 7 нежелательны для растворения стибнита.

\section{Методы и материалы}

Исследование материала и продуктов выщелачивания. Элементные анализы флотационного концентрата и кеков проводили на рентгеноспектральном флуоресцентном спектрометре AxiosMAX фирмы PANalytical. Фазовый анализ флотоконцентрата выполнен на дифрактометре XRD 7000 Maxima. Микрорентгеноспектральный анализ проведен на сканирующем электронном микроскопе Quanta 200 фирмы FEI. Содержание золота определяли пробирномасс-спектральным методом с индуктивно связанной плазмой на приборе NexION 350D. Pacтворы анализировали на масс-спектрометре с индуктивносвязанной плазмой ELANDRC-е.

Цианирование концентрата. К навеске флотоконцентрата массой 10 г добавляли выщелачивающий раствор в объеме $100 \mathrm{~cm}^{3}$ при Ж:Т=10:1. Емкости с полученной пульпой помещали в бутылочный агитатор, где пульпу перемешивали в течение 24 ч. Из содержимого отбирали аликвоты объемом $50 \mathrm{~cm}^{3}$, которые фильтровали и анализировали на содержание золота. Состав выщелачивающих растворов: концентрация $\mathrm{NaCN}-3,0$ г/дм³ $, \mathrm{NaOH}-2,0$ г/дм³ $, \mathrm{pH}=11,0$. Результаты цианидного выщелачивания золота из флотоконцентрата представлены в табл. 1.

Сульфидно-щелочное выщелачивание. Эксперименты по выщелачиванию сурьмы проводили при атмосферном давлении в стеклянных сосудах. Перемешивание осуществлялось за счет магнитной мешалки. Температура регулировалась за счет подогреваемой магнитной мешалки с постоянным магнитом. Использовали реактивы марки ХЧ. В смесь гидроксида на- 
Таблица 1. Результаты цианидного выщелачивания золота из исходного флотоконцентрата

Table 1. Resultsofagitated cyanide gold leaching test of flotationconcentrate

\begin{tabular}{|c|c|c|c|}
\hline $\begin{array}{c}\text { Исходное } \\
\text { содержание } \mathrm{Au}, \Gamma / \mathrm{T}\end{array}$ & $\begin{array}{c}\text { Концентрация } \mathrm{Au} \\
\text { в р-ре, мг/дм }\end{array}$ & Извлеченное $\mathrm{Au}, \Gamma / \mathrm{T}$ & Извлечение Аu, \% \\
\hline 60 & 1,822 & 18,22 & 30,4 \\
\hline
\end{tabular}

трия и сульфида натрия добавляли дистиллированную воду и нагревали до необходимой температуры, затем добавляли навеску флотационного концентрата 10 или 100 г. По окончании эксперимента пульпу фильтровали, полученный кек сушили и передавали на анализ с полной расшифровкой спектра.

Азотнокислотное выщелачивание. Опыты по азотнокислотному выщелачиванию проводили на обессурьмянистых кеках при атмосферном давлении в стеклянных сосудах. Перемешивание осуществлялось за счет механического агитатора при 250 мин $^{-1}$ и температуре $80-100{ }^{\circ} \mathrm{C}$.

\section{Результаты и их обсуждение}

Исследование исходного материала. Элементный состав флотационного концентрата представлен в табл. 2. Основные обнаруженные фазы: кварц $\left(\mathrm{SiO}_{2}\right)-43,7 \%$, стибнит $\left(\mathrm{Sb}_{2} \mathrm{~S}_{3}\right)-$ $28,9 \%$, кальцит $\left(\mathrm{CaCO}_{3}\right)-12,0 \%$, анкерит $\left(\mathrm{Ca}(\mathrm{Fe}, \mathrm{Mg}, \mathrm{Mn})\left(\mathrm{CO}_{3}\right)_{2}\right)$ (рис. 1). Такие ассоциации характерны для кварц-золотоантимонитовых полисульфидных руд, что относится ко второстепенному типу руд Олимпиадинского месторождения: существенно антимонитные с подчиненным содержанием других минералов [14, 15].

Микрорентгеноспектральный анализ исходного сырья показал наличие сурьмы $(19,69$ ат. \%), серы $(34,25$ ат. \%), железа (10,67 ат. \%), кислорода (26,63 ат. \%) и др. в исходном сырье, что подтверждает наличие кремнезема, стибнита, арсенопирита и пирита (рис. 2).

Выщелачивание сурьмы. Исследования по выщелачиванию сурьмы проводились с целью установления оптимальных параметров рассматриваемого технологического процесса. Изучаемыми параметрами являлись: температура, соотношение жидкого к твердому, время выщелачивания и концентрация гидроксида натрия (табл. 3). Концентрация $\mathrm{Na}_{2} \mathrm{~S}$ во всех опытах составляла 100 г/дм³.

Состав обессурьмянистых кеков представлен в табл. 4. Определены зависимости влияния температуры, времени и соотношения Ж:Т на извлечение сурьмы и серы из флотационного концентрата.

Как видим, извлечение сурьмы в раствор составило от 79,9 до 98,0 \%.

Таблица 2. Элементный состав флотационного концентрата АО «Полюс»

Table 2. Chemical composition of the flotation concentrate PJS "Polys"

\begin{tabular}{|c|c|c|c|c|c|c|c|c|c|c|}
\hline Элемент & $\mathrm{As}$ & $\mathrm{Ca}$ & $\mathrm{Fe}$ & $\mathrm{Mg}$ & $\mathrm{O}$ & $\mathrm{S}$ & $\mathrm{Sb}$ & $\mathrm{Si}$ & $\mathrm{Au}$ & Прочие \\
\hline мас. $\%$ & 1,9 & 13,14 & 8,95 & 1,46 & 23,15 & 12,01 & 20,59 & 15,71 & 58 г/т & 33,1 \\
\hline
\end{tabular}




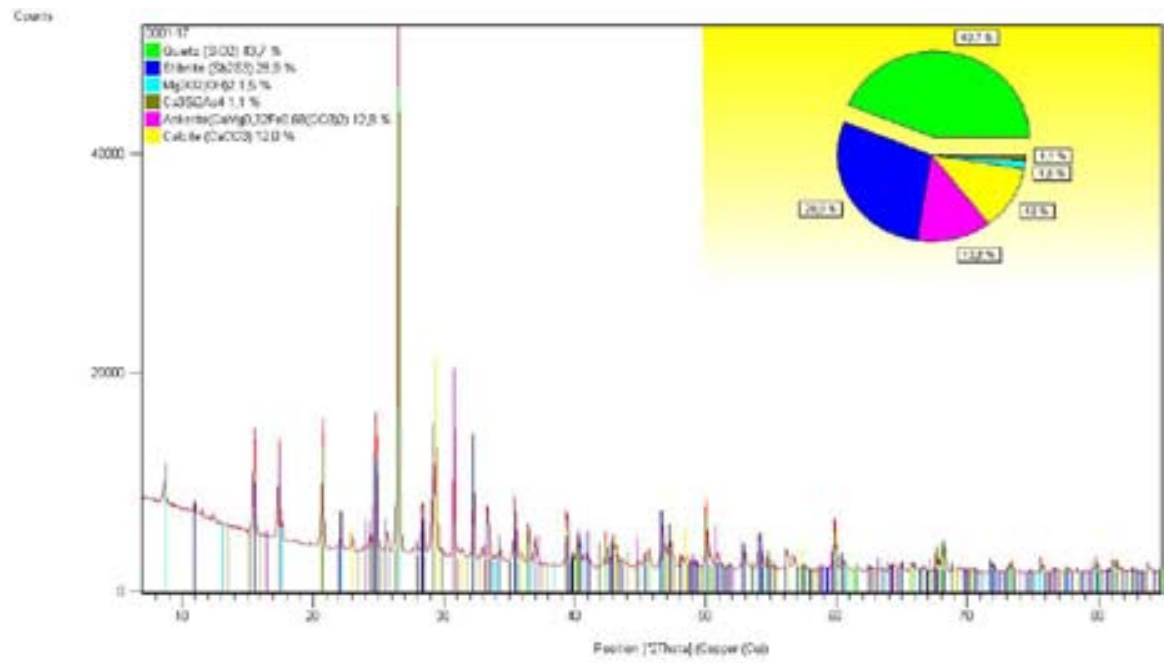

Рис. 1. Диффрактограмма исходного концентрата

Fig. 1. XRD pattern of flotation concentrate

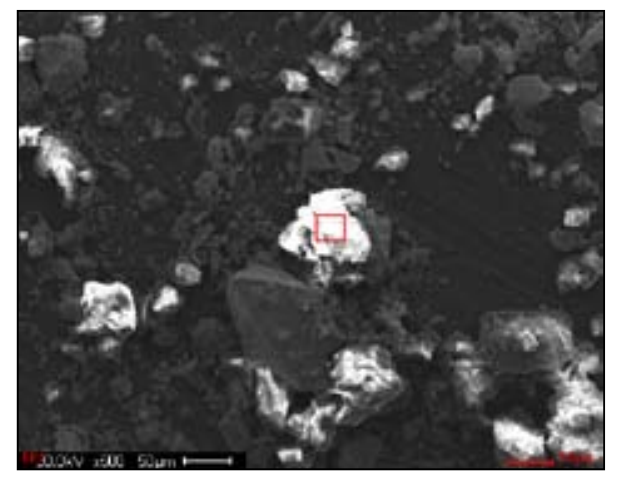

\begin{tabular}{ccc}
\hline Элемент & $\mathrm{Wt} \%$ & $\mathrm{At} \%$ \\
$\mathrm{O}$ & 08.65 & 26.63 \\
$\mathrm{As}$ & 01.42 & 00.93 \\
$\mathrm{Si}$ & 01.36 & 02.38 \\
$\mathrm{Au}$ & 01.40 & 00.35 \\
$\mathrm{~S}$ & 22.29 & 34.25 \\
$\mathrm{Sb}$ & 48.65 & 19.69 \\
$\mathrm{Ca}$ & 04.14 & 05.09 \\
$\mathrm{Ca}$ & 04.14 & 05.09 \\
$\mathrm{Fe}$ & 12.10 & 10.67 \\
\hline
\end{tabular}

Рис. 2. Микрофотография и локальный химический анализ выделенной области исходного концентрата

Fig. 2. SEM image with table with chemical elements of flotation concentrate

Как видим на графике (рис. 3), с ростом температуры увеличивается переход сурьмы в раствор, извлечение достигло 97 \%. Однако переход серы в раствор сократился пропорционально. С ростом концентрации $\mathrm{NaOH}$ переход серы в раствор увеличивается (рис. 4), а извлечение сурьмы снижается, что подтверждает исследования авторов [16], что добавление гидроксидионов в систему несколько увеличивает растворение серы.

Продолжительность выщелачивания флотоконцентратата и увеличение соотношения Ж:Т (рис. 5 и 6) значительно не повлияли на переход сурьмы в раствор, извлечение составило 97,5 и 97,1\% соответственно. Контрольный опыт при Ж:Т $=4: 1$, температуре $50{ }^{\circ} \mathrm{C}$ и времени выщелачивания 2 ч показал, что извлечение сурьмы снизилось на 10 \% и составило 87,9\%.

При увеличении времени выщелачивания возрастает извлечение. Максимальная степень извлечения сурьмы достигла 98 \% (рис. 7). Установлено, что продолжительность выщелачивания более 3 ч значительно не влияет на извлечение сурьмы в раствор. Таким образом, в целях 
Таблица 3. Параметры выщелачивания сурьмы

Table 3. Alkaline leaching's factors of antimony

\begin{tabular}{|c|c|c|c|c|c|}
\hline № п.П. & Температура, ${ }^{\circ} \mathrm{C}$ & Ж:Т & Время, ч & $\mathrm{C}_{\mathrm{NaOH}}, \Gamma / д \mathrm{M}^{3}$ & $\mathrm{C}_{\mathrm{Na} 2 \mathrm{~S}}$, Г/дм ${ }^{3}$ \\
\hline 1 & 30 & 6 & 3 & 40 & 100 \\
\hline 2 & 40 & 6 & 3 & 40 & 100 \\
\hline 3 & 50 & 6 & 3 & 40 & 100 \\
\hline 4 & 50 & 6 & 1 & 40 & 100 \\
\hline 5 & 50 & 6 & 2 & 40 & 100 \\
\hline 6 & 50 & 4 & 3 & 40 & 100 \\
\hline 7 & 50 & 2,5 & 3 & 40 & 100 \\
\hline 8 & 50 & 4 & 2 & 40 & 100 \\
\hline 9 & 50 & 4 & 3 & 40 & 100 \\
\hline 10 & 50 & 4 & 4 & 40 & 100 \\
\hline 11 & 50 & 4 & 5 & 40 & 100 \\
\hline 12 & 50 & 4 & 24 & 40 & 100 \\
\hline 13 & 60 & 4 & 4 & 40 & 100 \\
\hline 14 & 50 & 4 & 3 & 60 & 100 \\
\hline 15 & 50 & 4 & 3 & 80 & 100 \\
\hline
\end{tabular}

Таблица 4. Элементный состав обессурьмянистых кеков

Table 4. Chemical composition of the antymonyless cakes

\begin{tabular}{|c|c|c|c|c|c|c|c|c|}
\hline Элемент & $\mathrm{As}$ & $\mathrm{Ca}$ & $\mathrm{Fe}$ & $\mathrm{Mg}$ & $\mathrm{S}$ & $\mathrm{Sb}$ & $\mathrm{Si}$ & $\mathrm{Au}$ \\
\hline мас. \% & $3-3,4$ & $16,3-18,6$ & $10,9-14,5$ & $1,9-2,1$ & $5,50-8,0$ & $0,67-5,3$ & $19,2-20,6$ & $52,8-78,4$ г/т \\
\hline
\end{tabular}

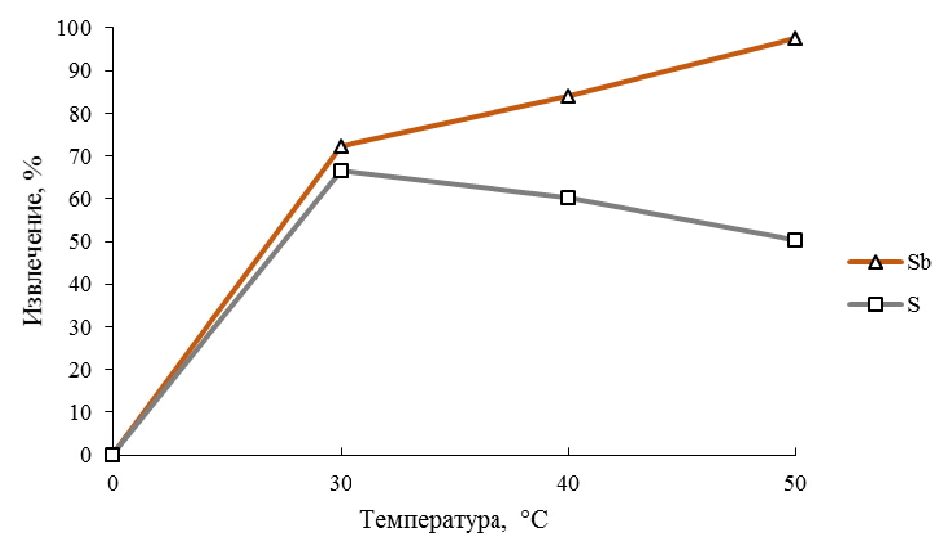

Рис. 3. График зависимости влияния температуры на извлечение сурьмы и серы в раствор

Fig. 3. Dependence of antimony and sulfur recovery on the temperature 


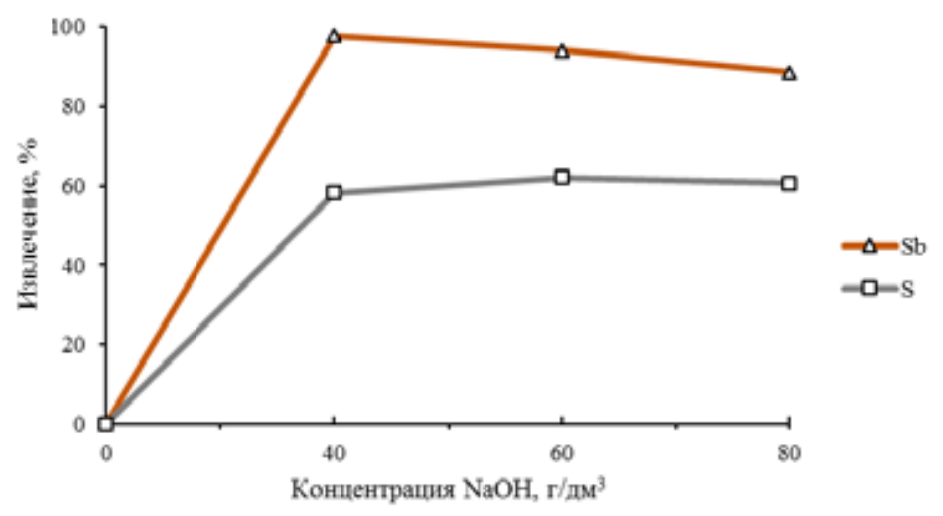

Рис. 4. График зависимости влияния концентрации $\mathrm{NaOH}$ на извлечения сурьмы и серы

Fig. 4. Dependence of antimony and sulfur recovery on $\mathrm{NaOH}$ concentration

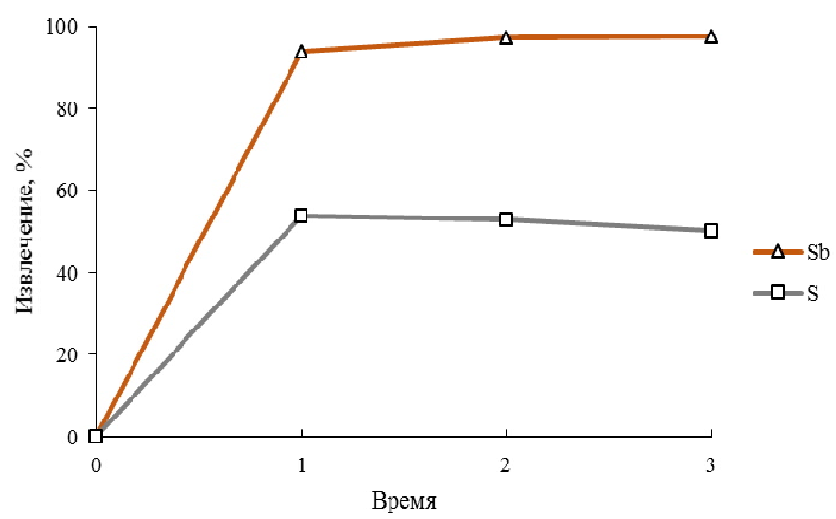

Рис. 5. График зависимости влияния времени выщелачивания на извлечение сурьмы и серы в раствор

Fig. 5. Dependence of antimony and sulfur recovery on the time

промышленной переработки золотосурьмянистых концентратов необходимо учитывать, что при сокращении соотношения жидкого к твердому необходимо увеличивать время выщелачивания.

При сульфидно-щелочном выщелачивании стибнита в растворе также образуются тиосульфаты [17]. Литературные данные показывают, что тиосульфатные соединения являются структурным аналогом сульфата, где один атом кислорода замещен атомом серы. Уникальность тиосульфата заключается в способности к комплексообразованию. Образование тиосульфата происходит по следующей реакции (8):

$$
\begin{aligned}
& 2 \mathrm{Na}_{2} \mathrm{~S}+2 \mathrm{O}_{2}+\mathrm{H}_{2} \mathrm{O}=\mathrm{Na}_{2} \mathrm{~S}_{2} \mathrm{O}_{3}+2 \mathrm{NaOH}, \\
& \Delta \mathrm{G}_{298}^{0}=-836 \text { кДж/моль . }
\end{aligned}
$$

Золото с тиосульфат-ионом образует прочный комплекс состава $\left[\mathrm{Au}\left(\mathrm{S}_{2} \mathrm{O}_{3}\right)_{2}\right]^{-3}$, изменение энергии Гиббса образования которого составляет -1024,9 кДж/моль, не разлагающийся с выде- 


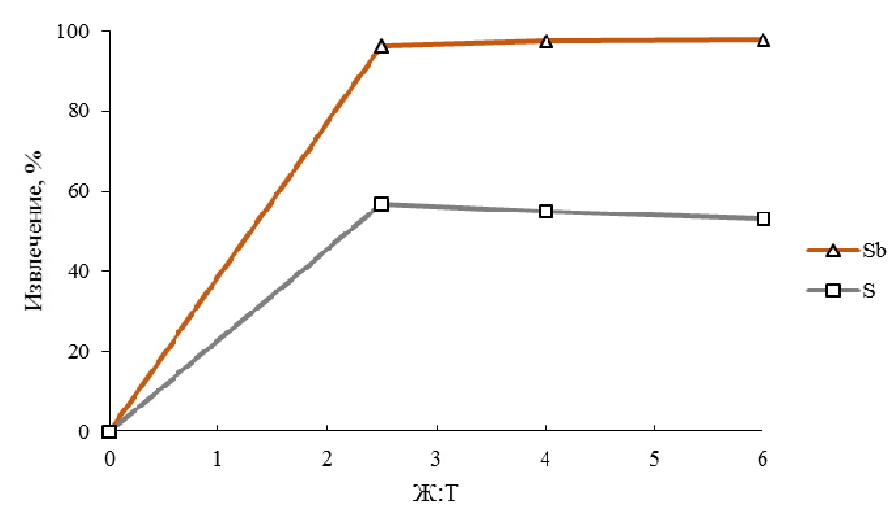

Рис. 6. График зависимости влияния Ж:Т на извлечение сурьмы и серы в раствор

Fig. 6. Dependence of antimony and sulfur recovery on L/S ratio

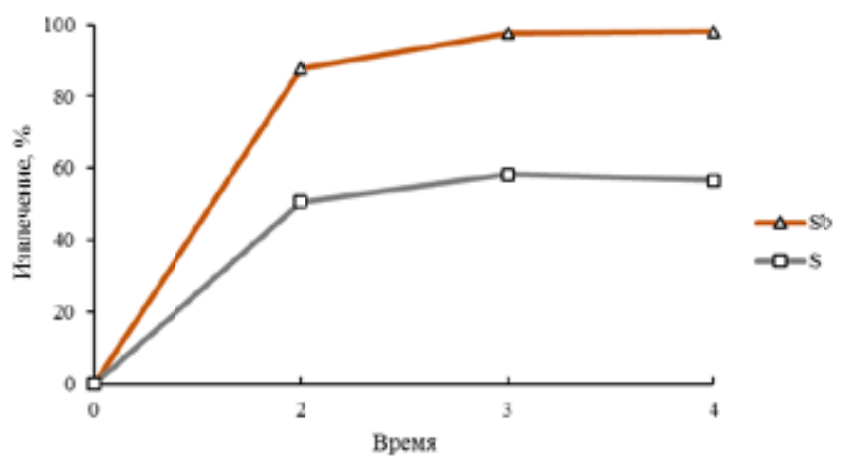

Рис. 7. График влияния времени на извлечение сурьмы и серы при Ж:Т $=4: 1$

Fig. 7. Dependence of antimony and sulfur recovery on the time Experiments conditions: L/S ratio 4:1

лением серы даже при подкислении. Процесс растворения золота в тиосульфате в присутствии кислорода протекает по реакции, аналогичной цианистому процессу:

$$
4 \mathrm{Au}+8 \mathrm{Na}_{2} \mathrm{~S}_{2} \mathrm{O}_{3}+\mathrm{O}_{2}+\mathrm{H}_{2} \mathrm{O}=4 \mathrm{Na}_{3}\left[\mathrm{Au}\left(\mathrm{S}_{2} \mathrm{O}_{3}\right)_{2}\right]+4 \mathrm{NaOH}
$$

Термодинамическая вероятность реакции 9 достаточно велика $\left(\Delta \mathrm{G}_{298}^{0}=-96,5\right.$ кДж/моль) и возрастает с повышением температуры. Таким образом, при длительном выщелачивании до $6 \%$ золота может переходить в раствор.

Цианирование обессурьмянистого кека. Цианирование обессурьмянистого кека проводилась по методике, описанной выше. Результаты цианирования золота из кека выщелачивания сурьмы сульфидно-щелочными растворами представлены в табл. 5.

По результатам опытов агитационного выщелачивания золота из флотоконцентрата и обессурьмянистого кека были получены достаточно низкие значения извлечения в раствор 30,4 и $32,2 \%$ соответственно.

Азотнокислотное выщелачивание. Поскольку результаты извлечения золота цианированием обессурьмянистого кека оказались неудовлетворительными, была предложена азотно- 
Таблица 5. Результаты цианирования обессурьмянистого кека

Table 5. Results of agitated cyanide gold leaching test of the antymonyless cakes

\begin{tabular}{|c|c|c|c|}
\hline $\begin{array}{c}\text { Исходное } \\
\text { содержание } \mathrm{Au}, \Gamma / \mathrm{T}\end{array}$ & $\begin{array}{c}\text { Концентрация } \mathrm{Au} \\
\text { в р-ре, мг/дм }\end{array}$ & Извлеченное $\mathrm{Au}, \Gamma / \mathrm{T}$ & Извлечение $\mathrm{Au}, \%$ \\
\hline 66 & 4,25 & 21,25 & 32,2 \\
\hline
\end{tabular}

Таблица 6. Результаты азотнокислотного выщелачивания обессурьмянистого кека

Table 6. Results of agitated nitric acid leaching tests of the antymonyless cakes

\begin{tabular}{|l|r|c|c|c|c|c|c|c|c|c|}
\hline \multirow{2}{*}{ Материал } & \multicolumn{2}{|c|}{$\mathrm{Fe}$} & \multicolumn{2}{c|}{$\mathrm{S}$} & \multicolumn{2}{|c|}{$\mathrm{As}$} & \multicolumn{3}{c|}{ Са } & \multicolumn{2}{c|}{ Аи (в кек) } \\
\cline { 1 - 14 } & $\%$ & Извл \% & $\%$ & Извл \% & $\%$ & Извл \% & $\%$ & Извл \% & Г/т & Извл \% \\
\hline $\begin{array}{l}\text { Декарбонизированный } \\
\text { кек }\end{array}$ & 1,01 & 93,4 & 15,8 & 41,7 & 1,00 & 77,6 & 17,80 & 24,6 & 99 & 93,2 \\
\hline Обессурьмянистый кек & 2,40 & 85,9 & 8,3 & 36,0 & 1,40 & 68,5 & 7,50 & 70,7 & 102 & 94,3 \\
\hline
\end{tabular}

кислотная технология $[18,19]$. В силу того, что исходный флотационный концентрат содержит 12 \% карбоната кальция $\left(\mathrm{CaCO}_{3}\right)$, применили дополнительно операцию декарбонизации. Далее брали навеску 50 г каждого из полученных материалов (обессурьмянистый кек и декарбонизированный кек), подвергали их азотнокислому выщелачиванию. Результаты опытов приведены в табл. 6.

Сравнивая результаты табл. 6, можно отметить, что переход железа, мышьяка и серы в раствор значительно выше у декарбонизированного кека, однако концентрирование золота оказалось больше у материала без дополнительной стадии декарбонизации.

\section{Выводы}

Высокое содержание сурьмы и других примесей осложняет извлечение золота из флотоконцентрата. При текущих мировых ценах на сурьму и золото становится рентабельным перерабатывать низкосортные руды. Рентгенофазовые и микрорентгеноспектральные анализы флотационного концентрата показали, что материал представлен в основном соединениями сурьмы, кремния, кальция, серы и железа. Такие ассоциации характерны для кварцзолотоантимонитовых полисульфидных руд.

Установлены оптимальные режимы сульфидно-щелочного выщелачивания: Концентрации $\mathrm{NaOH}-40$ г/дм ${ }^{3}, \mathrm{Na}_{2} \mathrm{~S}-100$ г/дм³, Ж:T $=4: 1$, температура выщелачивания 50-60 ${ }^{\circ} \mathrm{C}$, время выщелачивания 3 ч. Извлечение сурьмы из флотационного концентрата сульфидно-щелочными растворами достигало 94-98 \%.

Агитационное цианидное выщелачивание золота из флотационного концентрата и обессурьмянистого кека не дали высоких результатов: 30,4 и 32,2 \% соответственно, что подтверждает упорность материала.

Азотнокислотное выщелачивание обессурьмянистого кека доказало свою эффективность: содержание золота в нерастворимом осадке составило 102 г/т, что практически в 2 раза больше исходных концентраций. Поэтапная переработка флотационного концентрата позволяет вы- 
делить сурьму, железо, мышьяк и тем самым получить концентрированный по золоту остаток, пригодный к цианированию.

Статья подготовлена по материалам доклада, представленного на ІХ международном конгрессе «Цветные металлы и минералы-2017».

\section{Список литературы}

1. Категория: итоги производства и добычи золота в Российской Федерации по итогам 12 месяцев 2016 г. [Электронный ресурс]. Союз золотопромышленников, Режим доступа: http:// http:/goldminingunion.ru/news/news_post/ [Category: The results of gold production and extraction in Russian Federation for the 12 months of 2016. Gold Mining Union (In Russ.)]

2. Лодейщиков В.В. Технология извлечения золота и серебра из упорных руд. Иркутск: Иргиредмет, 1999. 452 c. [Lodeishchikov V.V. Technology of gold and silver recovery from refractory ores. Irkutsk: Irgiredmet, 1999. 452 p. (In Russ.)]

3. Меретуков М.А., Орлов А.М. Металлургия благородных металлов. Зарубежный опыт. М.: Металлургия, 1991. 416 c. [Meretukov M.A., Orlov A.M. Metallurgy of precious metals. Foreign experience. Moscow: Metallurgy, 1991. 416 p. (In Russ.)]

4. Котляр Ю.А., Меретуков.М. А., Стрижко Л.С. Металлургия благородных металлов. М.: МИСИС, 2005. 432 с. [Kotlyar Yu.A., Meretukov. М.A., Strizhko L.S. Metallurgy of precious metals. Moscow: MISIS, 2005. 432 p. (In Russ.)]

5. Захаров Б.А., Меретуков М.А. ЗОЛОТО: упорные руды. М.: Издательский дом «Руда и Металлы», 2013. 452 c. [Zakharov B.A., Meretukov M.A. GOLD: refractoryores. Moscow: Publishing hous "Ore\&Metals", 2013. 452 p. (In Russ.)]

6. Попсуев М.В., Скорик Л.Ф., Особенности переработки золото-сурьмянистых руд. Путь науки - Международный научный журнал 2016. Т. 4(26), С. 47-50. [Popsuev M.V., Skorik L.F. Features of gold-antimony ore processing. The Way of Science - International scientific journal 2016. Vol. 4(26), P. 47-50 (In Russ.)]

7. Категория: Sarylakh and Sentachan gold and antimony mines [Электронный pecypc]. Geopromining, Режим доступа: http://www.geopromining.com.

8. Ubaldini S. Process flow-sheet for gold antimony recovery from stibnite. Hydrometallurgy 2000. Vol. 57, P. 187-199.

9. Anderson C.G. and Krys L.E., Leaching of antimony from a refractory precious metals concentrate. Hydrometallurgy Fundamentals Technology and Innovations, Proceedings of the Milton E. Wadsworth (IV) International Symposium on Hydrometallurgy, ed. J.B. Hiskey and G. Warren. Society for Mining, Metallurgy and Exploration, 1993, Littleton, Co., P. 341-363.

10. Ubaldini S., Veglio F., Fornari P. Process flow-sheet for gold antimony recovery from stibnite. Hydrometallurgy 2000. Vol. 57, P. 187-199.

11. Sminčáková E., Raschman P. Leaching of Stibnite by Mixed $\mathrm{Na}_{2} \mathrm{~S}$ and $\mathrm{NaOH}$ Solutions. ACTA TECHNICA CORVINIENSIS-Bulletin of Engineering 2012. Vol. 5, P. 35-37.

12. Sminčáková E. Leaching of Natural Stibnite Using $\mathrm{Na}_{2} \mathrm{~S}$ and $\mathrm{NaOH}$ Solutions. International Journal of Energy Engineering 2011. Vol. 1(2), P. 85-89. 
13. Motang T., Tiancong Z. A thermodynamic study on the basic and negative potential fields of the systems of $\mathrm{Sb}-\mathrm{S}-\mathrm{H}_{2} \mathrm{O}$ and $\mathrm{Sb}-\mathrm{Na}-\mathrm{S}-\mathrm{H}_{2} \mathrm{O}$. Journal for Central South Institute of Mining and Metallurgy 1988. P. 35-43.

14. Волков А.В., Генкин А.Д., Гончаров В.И. О формах нахождения золота в рудах месторождений «Наталкинское» и «Майское» (Северо-Восток России). Тихоокеанская геология 2007, T. 25(6), C. 18-29. [Volkov A.V, Genkin A.D., Goncharov V.I. About the forms of gold in the ores of the Natalkinskoye and Maiskoye deposits (the North-East of Russia). Pacific Geology 2007. Vol. 25(6), P. 18-29. (In Russ.)]

15. Категория: Олимпиадинское (Au) месторождение [Электронный ресурс]. Минералы и месторождения России и стран ближнего зарубежья. Режим доступа: http://webmineral.ru/ deposits/item.php?id=1251 [Category: Olimpiadinskoe ( $\mathrm{Au}$ )deposit. Minerals and deposits of Russia and CIS countries (In Russ.)]

16. Чубаров А.В., Белоусова Н.В., Казаченко А.С., Максименко В.В. Растворение элементной серы в системах $\mathrm{S}-\mathrm{H}_{2} \mathrm{O}-\mathrm{OH}^{-}-\mathrm{S}^{2-}$. Журнал Сибирского федерального университета. Химия 2008, № 1(3), C. 235-241 [Chubarov A.V., Belousova N.V., Kazachenko A.S., Maksimenko V.V. Dilution of Elemental Sulfur in Systems $\mathrm{S}-\mathrm{H}_{2} \mathrm{O}-\mathrm{OH}^{-}-\mathrm{S}^{2-}$. Journal of Siberian Federal University. Chemistry 2008, Vol. 1(3), P. 235-241. (In Russ)]

17. Каковский И.А., Поташников Ю.М. Кинетика процессов растворения. М.: Металлургия, 1975. 224 с. [Kakovskii I.A., Potashnikov Yu.M. Kinetics of dissolution processes. Moscow: Metallurgy, 1975. 224 p. (In Russ.)]

18. Судаков Д.В., Челноков С.Ю., Русалев Р.Э., Елшин А.Н. Технология и оборудование для гидрохимического окисления упорных золотосодержащих концентратов (ES-процесс). Цветные металль 2017. № 3, С. 40-44. [Sudakov D.V., Chelnokov S.Yu., Rusalev R.E., Elshin A.N. Technology and Equipment for Hydrometallurgical Oxidation of Refractory Gold-Bearing Concentrates (ES-Process). Tsvetnye Metally 2017, Vol. 3, P. 40-44 (In Russ.)]

19. Rogozhnikov D.A., Mamyachenkov S.V., Anisimova O.S. Nitric acid leaching of copper-zinc sulfide middlings. Metallurgist 2016, Vol. 60, P. 229-233. 